\title{
Bukkal Bölgeden Kaynaklanan Pleomorfik Adenom: Olgu Sunumu
}

\author{
Pleomorphic Adenoma of the Buccal Region: Case Report
}

\section{Şemsettin OKUYUCU ${ }^{1}$, Mehmet İhsan GÜLMEZ ${ }^{1}$, Gül Soylu ÖZLER ${ }^{1}$, Hasan DEMİREL ${ }^{1}$}

${ }^{1}$ Mustafa Kemal Üniversitesi, KBB A.D., HATAY

\section{ÖZET}

Tükürük bezi tümörleri tüm baş-boyun tümörlerinin \%34’ünü oluşturmaktadır. Benign mikst tümör olarak da bilinen pleomorfik adenom tükürük bezlerinin en sik görülen benign tümörüdür. En sık major tükürük bezlerinde görülür(\%92). Minör tükürük bezinden köken alan pleomorfik adenomlar en sık damakta görülür, bunu üst dudak ve bukkal bölge takip etmektedir. Etyolojisi tam olarak bilinmemekle birlikte günümüzde birleştirici kanalın epitel ve miyoepitel hücrelerine dönüşme kapasitesine sahip bağımsız bir rezerv hücresinden kaynaklandığı düşünülmektedir. Nadiren malign transformasyon gösterebilir ve sıklıkla uzun süredir var olan tümörlerde görülür. Bu durum tanıdan sonraki ilk 5 yıl içerisinde \%1,5 iken,15 yılı aştığında risk \%10 olmaktadır. Bu olgu sunumunda 15 yıldır bukkal bölgede yerleşen pleomorfik adenom olgusu sunulacaktır.

Anahtar Kelimeler: Bukkal kitle, pleomorfik adenom, minör tükürük bezi tümörü
ABSTRACT

Salivary gland tumors constitutes $3-4 \%$ of all head and neck tumors. Pleomorphic adenoma, also known as benign mixt tumor, is the most common benign salivary gland tumor. It arises most commonly from major salivary glands (92\%). Pleomorphic adenomas which arise from minor salivary glands are mostly seen at hard palate, upper lip and buccal region respectively. Although the etiology is not fully understood, today, it is thought that it arises from an independent reseve cell which have capable of giving rise to epithelial and myoepithelial cells of intercalated duct. Malignant transformation is rarely seen and it is often seen in long standing tumors. The risk is $1.5 \%$ in first 5 years after diagnosis, and $10 \%$ if it exceeds to 15 years. In this case report, we presented a buccal pleomorphic adenoma which is present for 15 years.

Keywords: Buccal mass, pleomorphic adenoma, minor salivary gland tumor

* Bu olgu sunumu 2-6 Kasım 2013 tarihleri arasında Antalya'da gerçekleştirilen “35. Türk Ulusal Kulak Burun Boğaz ve Baş Boyun Cerrahisi Kongresi’nde poster bildiri olarak sunulmuştur

\section{GíRiş}

Tükürük bezi tümörleri, tüm baş-boyun tümörlerinin \%3-4 ünü oluşturmaktadır. Benign mikst tümör olarak da bilinen pleomorfik adenom tükürük bezlerinin en sık görülen benign tümörüdür. En sık major tükürük bezlerinde görülmekle birlikte (\%92), üst solunum yolu ve gastrointestinal sistemdeki minör tükürük bezlerinde de görülebilmektedir (\%8) (1). Major tükürük bezleri içerisinde en sık parotis bezinde gözlenir. Sıklıkla 3060 yaş arasında görülür, kadınlarda erkeklere oranla 
daha sık rastlanmaktadır (2). Minör tükürük bezinden köken alan pleomorfik adenomlar en sik damakta görülür, bunu üst dudak ve bukkal bölge takip etmekte, ek olarak dil tabanı, retrofaringeal boşluk, pterigopalatin boşluk, lateral nazal duvar, nazal septum, trakea ve yüz cildinde de görülebilmektedir $(1,3,4)$.

Pleomorfik adenomun etyolojisi tam olarak bilinmemekle birlikte günümüzde birleştirici kanalın (intercalated duct) epitel ve miyoepitel hücrelerine dönüşme kapasitesine sahip bağımsız bir rezerv hücresinden kaynaklandığı düşünülmektedir $(3,4)$. Hastalar klinik olarak genellikle ağrısız, yavaş büyüyen bir kitle ile başvururlar. Semptomların süresi değişkendir (4). Makroskopik olarak sert, iyi sınırlı, yer yer lobüler yap1 gösterebilen, çevre dokulardan net birsınır hattıyla ayrılan kitleler olarak gözlenirler (5). Histolojik olarak hemen bütün pleomorfik adenomların ince kapsülü olduğu ve bu kapsülde yer yer ince flamanlar şeklinde uzantıların (psödopod) varlığı gözlenir. $\mathrm{Bu}$ psödopodlar nedeniyle oluşabilecek rekürrensi engellemek için cerrahi eksizyonun bir miktar normal dokuyu da içine alacak şekilde yapılması önerilmektedir (3).
Pleomorfik adenom nadiren malign transformasyon gösterebilir ve sıklıkla uzun süredir varolan tümörlerde görülür. Bu durum tanıdan sonraki ilk 5 yıl içerisinde \%1,5 iken, 15 yılı aştı̆̆ında risk \%10 olmaktadır (3).

$\mathrm{Bu}$ çalışmada 15 yıldır bukkal bölgede yerleşen pleomorfik adenom olgusu sunulmuş ve pleomorfik adenomların atipik yerleşimleri ile bunun ayırıcı tanısı tartışılmıştır.

\section{OLGU}

Elli bir yaşında kadın hasta kliniğimize sol yanakta şişlik şikâyeti ile başvurdu (Resim 1). Kitlenin varlığını 15 y1l önce fark etmiş ve kitle bu süre zarfında yavaş yavaş büyümüş. Ağrı hiç olmamış. Hastanın klinik muayenesinde sol bukkal bölgede bulunan, palpasyonda ağrısız, lastik kıvamında, düzgün yüzeyli, sınırları belirgin, ekstraoral ve minimal intraoral ekspansif kitle mevcuttu. Hastanın yapılan kontrastlı BT görüntülemesinde sol bukkal bölgede cilt altında, hafif ve homojen kontrast tutulumu gösteren, 27x20 $\mathrm{mm}$ boyutlu, ciltte deplasmana neden olan, sinırları belirgin, kapsüllü kitle mevcuttu (Resim 2).

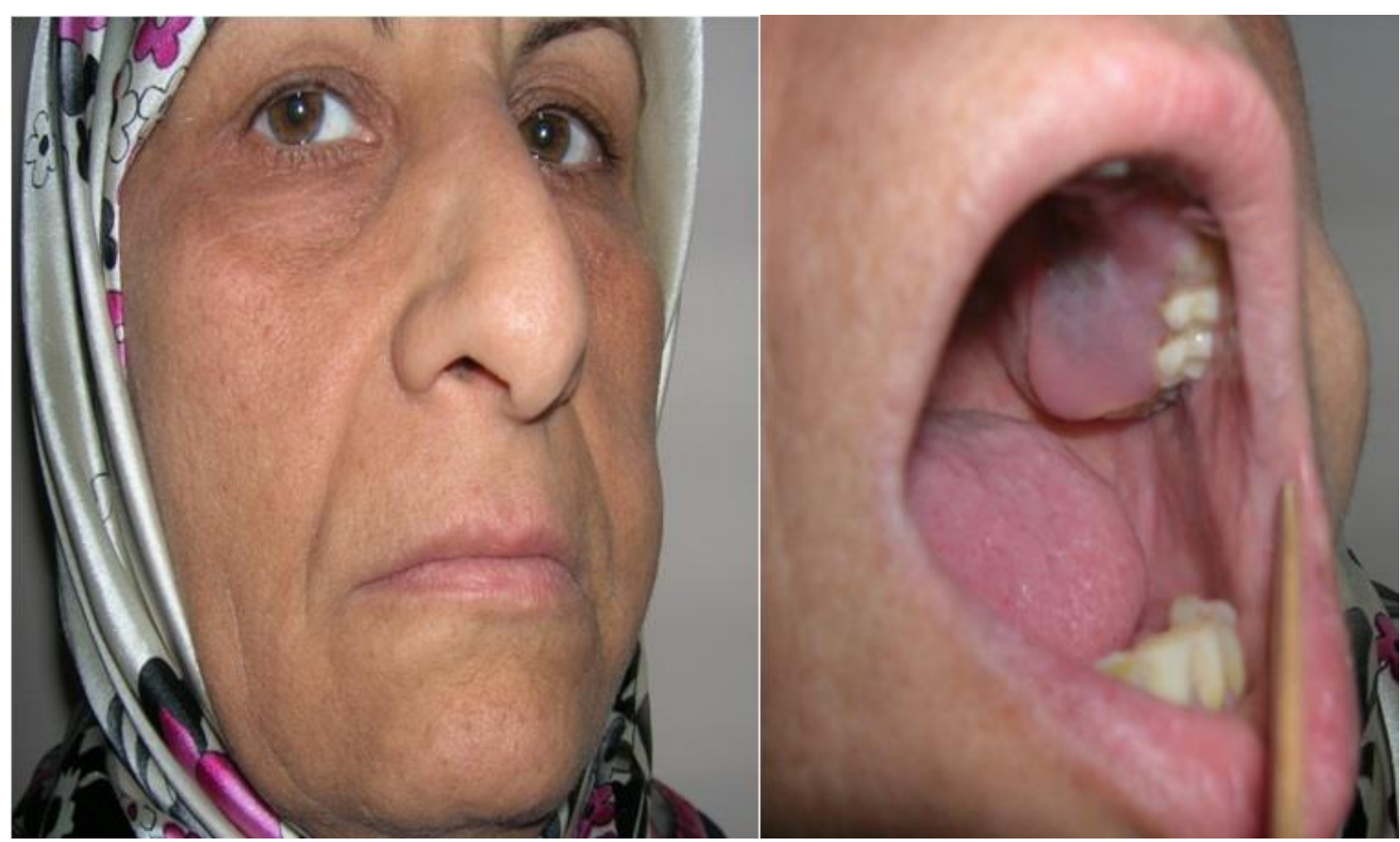

Resim 1: Preoperatif görünüm 
Yapılan MRI görüntülemede T1 sekansında orta derece sinyal veren, T1 inversion recovery (STIR) da yüksek sinyal veren düzgün sınırlı kitle gözlendi (Resim 2). Kitlenin genel anestezi altında transoral yaklaşımla eksizyonu planlandi. Total olarak eksize edilen kitle histopatolojik olarak değerlendirilmek üzere patoloji bölümüne gönderildi. İnceleme sonucu; $2,5 \times 2,2 \times 3 \mathrm{~cm}$ boyutlarında, düzgün ve parlak yüzeyli, kesit yüzeyi gri beyaz renkte, homojen görünümde, pleomorfik adenom ile uyumlu kitle şeklinde raporlandı. Hastanın ameliyatı ve sonrası dönemde herhangi bir komplikasyon ile karşılaşılmadı ve 1 yıllık takibinde nüks gözlenmedi (Resim 3). Hastadan uygulanacak tedavi ve mevcut verilerin bilimsel amaçlı kullanılabileceğine dair onam alind1.

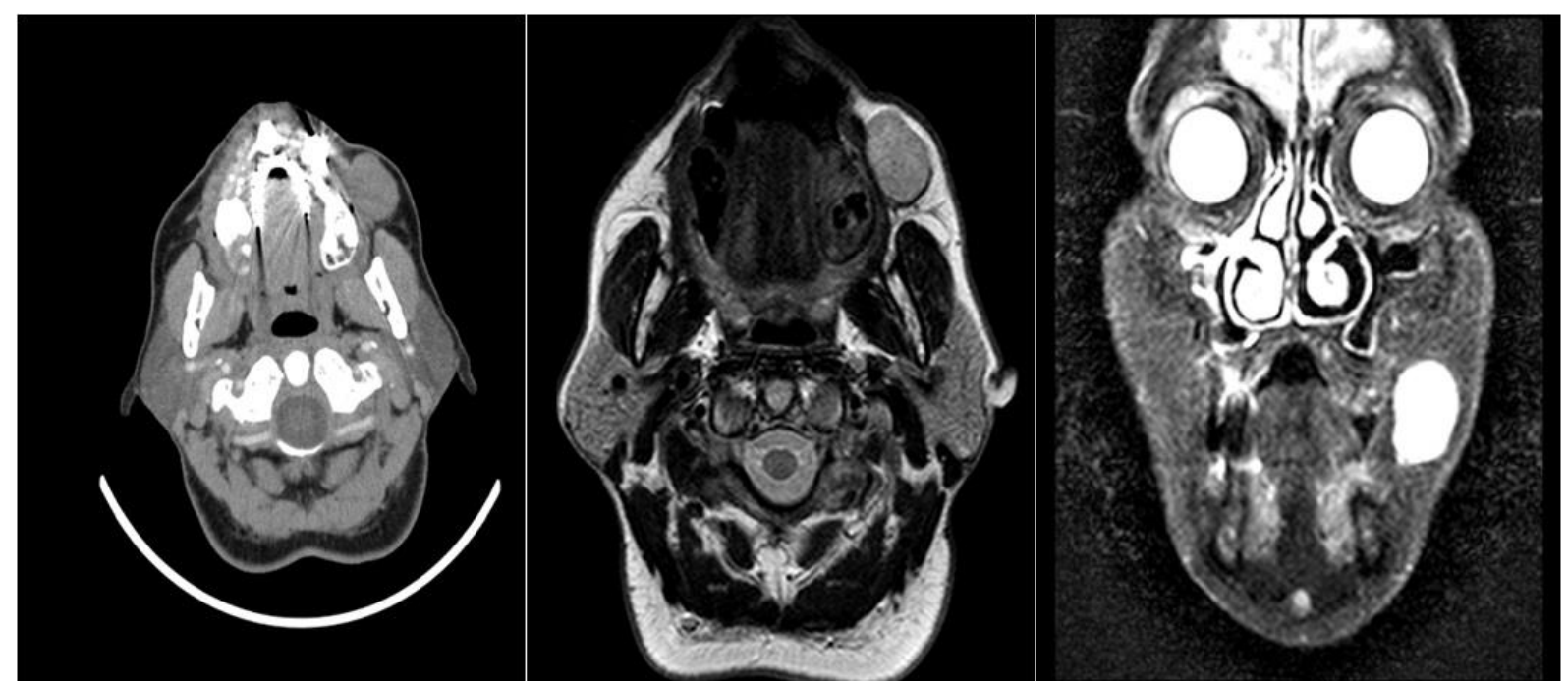

Resim 2:Kontrastlı Bilgisayarlı Tomografi (Aksiyel plan) kesitleri ve MRI görüntülemesi (Koronal plan-T1)

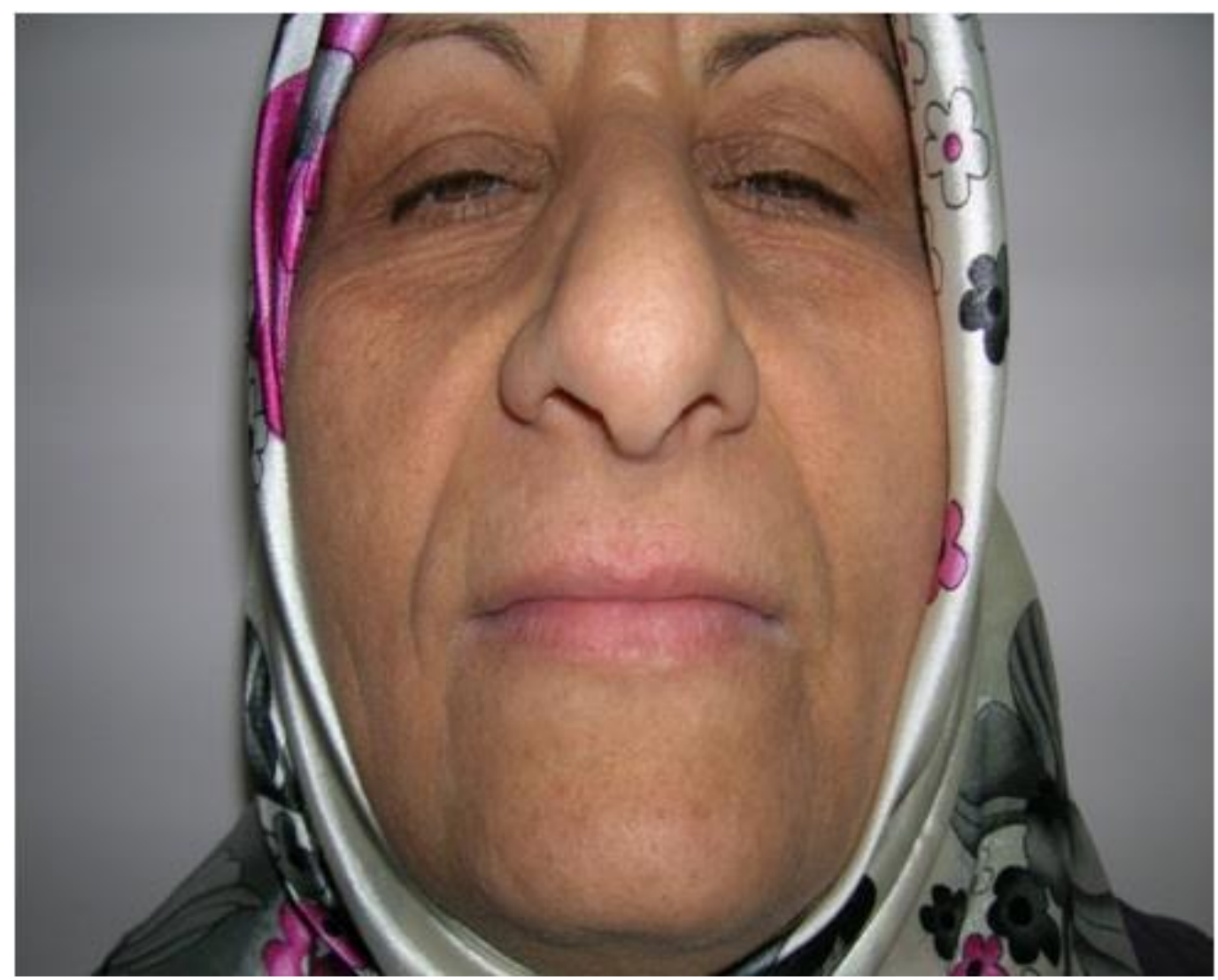

Resim 3:Postoperatif görünüm 


\section{TARTIŞMA}

Pleomorfik adenom tükürük bezlerinin en sık görülen tümörü olup, \%92 oranında major tükürük bezlerinde, \%8 oranında da minör tükürük bezlerinde görülmektedir (3). Minör tükürük bezi tümörleri ile ilgili olarak Pawelec ve ark.'nın yaptığı çalışmada minör tükürük bezlerinde görülen tümörlerin \% 36,8'i benign, \%63,2'si malign olarak tespit edilmiştir (6). Pleomorfik adenom bu benign tümörlerin \%81'ini, tüm tümörlerinse \%29,8'ini oluşturarak adenoid kistik karsinomdan sonra ikinci sıklıkta görülen minör tükürük bezi tümörü olarak göze çarpmaktadır (6). Pires ve ark.'nın yaptığı 546 vakadan oluşan çalışmada intraoral minör tükürük bezlerinde görülen tümörlerin \%55,9'unun benign, \%44,1'inin malign olduğu, pleomorfik adenomun benign tümörlerin \%59,3'ünü, tüm tümörlerin \%33,2'sini oluşturduğu tespit edilmiştir (2). Yine aynı çalışmada intraoral minör tükürük bezlerinde görülen pleomorfik adenomun en sik yerleşim bölgesi \%39,8 oranıyla damak olup bunu \%27,6 ile üst dudak, \%18,2 ile bukkal bölge takip etmektedir (2).

Pleomorfik adenomlar klinik olarak genelde y1llar içerisinde büyüyen ağrısız solid kitle şeklinde karşımıza çıkar. Bizim olgu sunumumuzda da 15 yıldır var olan, ağrısız ve solid bir kitle mevcuttu.

Bukkal bölgeden kaynaklanan bir kitlenin ayırıcı tanısında çeşitli kistik oluşumlar, hematom, masseter kas hipertrofisi, intramasseterik abse, tükürük bezi tümörleriyle birlikte diğer benign ve malign tümörler de düşünülebilir. Bizim vakamızda dermoid kist, sebase kist gibi kistik oluşumlar yapılan CT görüntülemesi doğrultusunda dışlanmıştır, çünkü kist içeriğinin kontrast tutması beklenmemektedir. İntermasseterik abse hastada lezyon bölgesinde enflamasyon bulgularının gözlenmemesi nedeniyle düşünülmemiştir. Hematom, hastada travma öyküsünün bulunmaması nedeniyle dışlanmıştır. Masseter kas hipertrofisi, bilateral masseter kasın diffüz büyümesiyle karakterize benign bir durumdur. Ancak hastanın görüntülemelerinde görülen kitlesel lezyon nedeniyle bu durum da dişlanmıştır.

Hastada bir tükürük bezi tümörü olması muhtemeldi, yerleşim yeri itibariyle parotis ve submandibular beze yakın yerleşik durumda ve bu bezlerle bağlantısı olmasa dahi minör tükürük bezi tümörlerinin olası yerleşim yerine uygun bir lokalizasyonda bulunmaktaydı. Pleomorfik adenom CT de tipik olarak; yumuşak doku dansitesinde, iyi sınırlı, homojen veya heterojen kontrast tutulumu gösteren kitlesel lezyon olarak görülür (1). MRI da ise T1 sekansında düşük veya orta düzeyde sinyal veren, T2 sekansinda ise hücresel açıdan yoğun alanlarda yüksek, miksoid açıdan yoğun bölgelerde çok yüksek sinyal veren kitleler olarak kendini gösterir (1). Hastaya yapılan görüntüleme yöntemlerinde bu bulgularla paralel özellikler gösteren kitlesel lezyonun gözlenmesi hastada benign veya düşük grade bir malign tükürük bezi tümörü olabileceğini düşündürmüş olup, yüksek grade malign tükük bezi tümörünü dışlamamıza neden olmuştur. Ayırıcı tanıda düşünülen diğer patolojiler arasında hemanjiyom, ekstranodal tutulumun daha belirgin olduğu Non-Hodgkin lenfoma, rabdomyom, şvannom ve diğer yumuşak doku tümörleri düşünülmüştür.

Pleomorfik adenomların hemen hepsinde ince bir kapsül ve bu kapsülden ince flamanlar şeklinde psödopodların varlığı gözlenir (3). Tedavide yetersiz rezeksiyon lokal rekürrense yol açmaktadır. Bu nedenle pleomorfik adenomun tedavisi tümör negatif cerrahi sınırlar içeren geniş eksizyondur, tümör dokusu ile birlikte bir miktar sağlam doku da çıkarılmalıdır (4).

Pleomorfik adenomda malign transformasyon riski düşük olmakla birlikte bu ihtimal zamanla artmaktadır. Malign transformasyon riski tanıdan sonraki ilk 5 yıl içerisinde \%1,5 iken, 15 yılı aştığında risk \%10 olmaktadir (3).

Sonuç olarak, tükürük bezi tümörleri içerisinde önemli bir yere sahip olan pleomorfik adenomun, malign 
transformasyon riski de göz önünde bulundurularak, klinik ve uygun radyolojik değerlendirmeler sonrasında cerrahi olarak tedavi edilmesi gerekmektedir. Nüks ve malign transformasyon riski nedeniyle hastaların operasyon sonrası uzun süreli takip edilmeleri uygun olacaktır.

\section{KAYNAKLAR}

1. Lingam RK, Daghir AA, Nigar E, Abbas SA, Kumar M. Pleomorphic adenoma (benign mixed tumour) of the salivary glands: its diverse clinical, radiological, and histopathological presentation. $\mathrm{Br}$ J Oral Maxillofac Surg. 2011; 49(1): 14-20.

2. Pires FR, Pringle GA, de Almeida OP, Chen SY. Intra-oral minor salivary gland tumors: a clinicopathological study of 546 cases. Oral Oncol. 2007; 43(5): 463-70.
3. Cummings $\mathrm{CW}$, Tükrük Bezlerinin Benign Tümörleri. In: Hanna EY, Lee S, Fan CY, Suen JY, editors. Cummings Otolaringoloji Baş ve Boyun Cerrahisi. Ankara: Güneş Tıp Kitabevleri, 2007: 1348-77.

4. Mendenhall WM, Mendenhall CM, Werning JW, Malyapa RS, Mendenhall N P. Salivary gland pleomorphic adenoma. Am J Clin Oncol. 2008; 31(1): 95-9.

5. Koç C, Tükrük Bezi Tümörleri. In: Yılmaz O, Vuralkan E, Tokgöz SA, editors. Kulak Burun Boğaz Hastalıkları ve Baş-Boyun Cerrahisi. Ankara: Güneş Tıp Kitabevleri, 2013: 787-802

6. Wyszyńska-Pawelec G, Gontarz M, Zapała J, Szuta M. Minor salivary gland tumours of upper aerodigestive tract: a clinicopathological study. Gastroenterol Res Pract. 2012 May 2. doi:10.1155/2012/780453. [Epub ahead of print]. 